\title{
PERANCANGAN SISTEM INFORMASI PENERIMAAN SISWA BARU BERBASIS WEB (STUDI KASUS : SMP PLUS BABUSSALAM BANDUNG)
}

\author{
Regi Witanto ${ }^{1)}$,Hanhan Hanafiah Solihin ${ }^{2}$ \\ Program studi Sistem Informasi ${ }^{12)}$ \\ Universitas Sangga Buana YPKP Bandung ${ }^{1) 2}$ \\ regiwitanto4@gmail ${ }^{1)}$, hanhan.hanafiah@yahoo.com ${ }^{2)}$
}

\begin{abstract}
Abstrak
Siswa baru yang mendaftar di SMP Plus Babussalam, khususnya untuk masuk ke pesantren, mayoritas berasal dari luar kota. Proses penerimaan siswa baru (PSB) di sekolah ini yang masih menggunakan sistem konvensional, sehingga calon siswa terkadang kesulitan mendapatkan informasi untuk melakukan proses pendaftaran. Proses administrasi juga cenderung lambat, karena data belum terintegrasi dan terkelola dengan baik. Proses ini juga masih menggunakan arsip dalam bentuk fisik yang rentan mengalami kerusakan atau bahkan hilang. Untuk dapat mengatasi permasalahan yang terjadi pada pendaftaran siswa baru di SMP Plus Babussalam dibuatlah perancangan dan pembangunan aplikasi Sistem Informasi Penerimaan Siswa Baru Berbasis Web. Metode yang digunakan untuk pembangunan sistem informasi menggunakan Model Prototype dengan pendekatan sistem berorientasi objek yang dimodelkan menggunakan UML (Unified Modelling Language). Hasil akhir dari perancangan dan pembangunan sistem informasi ini adalah adanya sebuah aplikasi yang dapat memberi kemudahan akses informasi dan proses pendaftaran sehingga proses administrasi penerimaan siswa baru menjadi lebih efektif dan efisisen.
\end{abstract}

Kata Kunci : sistem informasi, penerimaan siswa baru, prototype, UML, web

\section{PENDAHULUAN}

Perkembangan teknologi informasi khususnya internet tentu disambut baik oleh semua kalangan, salah satunya bahkan telah merambah ke dunia pendidikan sejak beberapa tahun terakhir. Sehingga hal ini menciptakan persaingan yang kompetitif diantara setiap lembaga pendidikan, tidak terkecuali lembaga pendidikan swasta.

SMP Plus Babussalam merupakan sekolah swasta yang berlandaskan islam dan memiliki sistem pesantren didalamnya. Salah satu aktivitas akademik yang ada di sekolah ini setiap kali menjelang tahun ajaran baru tentunya adalah proses penerimaan siswa baru (PSB). Siswa baru yang mendaftar di SMP Plus Babussalam, khususnya untuk masuk ke pesantren, mayoritas berasal dari luar kota. Namun, karena proses penerimaan siswa baru di sekolah ini yang masih menggunakan sistem konvensional, sehingga calon siswa yang berasal dari luar kota terkadang kesulitan untuk mendapatkan informasi dan melakukan proses pendaftaran.
Sistem yang masih konvensional ini juga mengakibatkan proses administrasi penerimaan siswa baru cenderung lambat, karena data siswa baru yang telah mendaftar belum terintegrasi dan terkelola dengan baik. Sistem ini juga masih menggunakan arsip dalam bentuk fisik yang rentan mengalami kerusakan atau bahkan hilang. Sehingga kebutuhan akan suatu konsep dan mekanisme penerimaan siswa baru dengan memanfaatkan teknologi informasi menjadi hal yang perlu dipertimbangkan.

Sehingga masalah yang terjadi dapat diidentifikasikan sebagai berikut :

1. Proses penerimaan siswa baru masih menggunakan sistem konvensional sehingga calon siswa yang berasal dari luar kota terkadang merasa kesulitan untuk mendapatkan informasi dan melakukan proses pendaftaran.

2. Proses administrasi penerimaan siswa baru cenderung lambat, karena data calon siswa yang telah mendaftar belum terintegrasi dan terkelola dengan baik. 
3. Masih menggunakan arsip dalam bentuk fisik sehingga rentan mengalami kerusakan atau bahkan hilang.

Dari masalah yang telah diidentifikasikan, tujuan yang ingin dicapai pada penelitian ini adalah :

1. Melakukan analisis dan perancangan sistem informasi penerimaan siswa baru berbasis web di SMP Plus Babussalam agar dapat memberi kemudahan akses informasi dan proses pendaftaran bagi calon siswa.

2. Merancang suatu sistem informasi berbasis web yang dapat mengatasi pengolahan data calon siswa agar data dapat lebih terintegrasi dan terkelola dengan baik.

3. Membuat suatu sistem informasi berbasis web yang dapat memudahkan proses administrasi pendaftaran sehingga memberi kemudahan bagi panitia penerimaan siswa baru di SMP Plus Babussalam.

Agar penelitian ini lebih terarah dan memudahkan dalam pembahasan, maka perlu adanya batasan permasalahan yang dibahas dalam pembuatan sistem informasi, adapun batasan masalah adalah sebagai berikut:

1. Perancangan sistem informasi berbasis web ini tidak membahas mengenai proses pembayaran administrasi pendaftaran sehingga tidak ada kaitannya dengan bagian keuangan.

2. Sistem informasi berbasis web ini tidak menyediakan fasilitas untuk melakukan tes secara online atau ujian online.

3. Sistem informasi berbasis web ini tidak membahas mengenai proses pemberian nilai ujian seleksi yang dilaksanakan di SMP Plus Babussalam.

\section{LANDASAN TORI}

\section{Pengertian Sistem}

Lucas mendefinisikan, "Sistem sebagai suatu komponen atau variabel yang terorganisir, saling berinteraksi, saling bergantung satu samalain dan terpadu". [1]

\section{Pengertian Informasi}

"Informasi adalah Data yang diolah menjadi bentuk yang lebih berguna dan lebih berarti bagi yang menerimanya". [3]

\section{Pengertian Sistem Informasi}

Pengertian sistem informasi menurut Robert A. Leitch \& K. Roscoe Davis, "Sistem informasi adalah suatu sistem didalam suatu organisasi yang mempertemukan kebutuhan pengolahan transaksi harian, mendukung operasi bersifat manajerial dan kegiatan strategi-strategi dari suatu organisasi dan menyediakan pihak luar tertentu dengan laporan-laporan yang diperlukan". [3]

\section{Pengertian Penerimaan Siswa Baru} (PSB)

Menurut Desi Anwar, "Penerimaan merupakan penyambutan, proses, perbuatan atau sikap terhadap seseorang". "Siswa merupakan pelajar pada akademi atau perguruan tinggi". "Baru merupakan suatu hal belum ada sebelumnya". [5]

\section{Pengertian Perancangan}

"Perancangan adalah suatu kegiatan yang memiliki tujuan untuk mendesign sistem baru yang dapat menyelesaikan masalah-masalah yang dihadapi perusahaan yang diperoleh dari pemilihan alternatif sistem yang terbaik". [1]

\section{METODE}

Untuk metode dalam pembangunan perangkat lunak sistem informasi ini menggunakan model Prototype, yaitu model metodologi pengembangan perangkat lunak yang menitik beratkan pada pendekatan aspek desain, fungsi dan user-interface.

Berikut gambar pengembangan perangkat lunak Model Prototype dapat dilihat pada gambar 1.

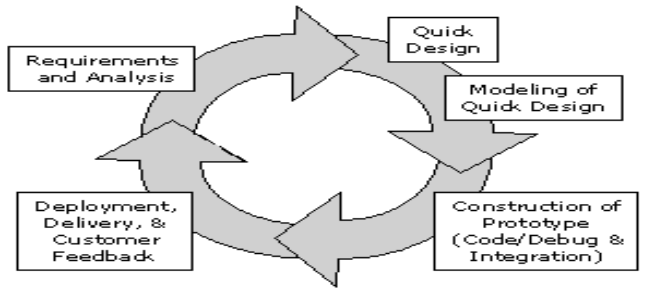

Gambar 1. Pengembangan Perangkat Lunak Model Prototype. [6]

\section{PEMBAHASAN}

\section{Analisis Prosedur yang Sedang Berjalan}

Analisis prosedur yang sedang berjalan akan menguraikan secara sistematis mengenai aktivitas yang terjadi pada prosedur penerimaan siswa baru (PSB) yang sedang berjalan di SMP Plus Babussalam, yakni sebagai berikut:

1. Peserta PSB datang ke lokasi SMP Plus Babussalam untuk melakukan pendaftaran. 
2. Panitia PSB akan memberikan formulir pendaftaran beserta rincian persyaratan berupa berkas-berkas yang harus dilengkapi.

3. Peserta PSB mengisi formulir, dan menyerahkan formulir tersebut bersama berkas-berkas persyaratan untuk diverifikasi oleh panitia PSB.

4. Peserta PSB yang dinyatakan lolos verifikasi akan diberi tanda bukti pendaftaran dan diberitahu untuk melaksanakan serangkaian ujian seleksi.

5. Peserta PSB mengikuti ujian seleksi masuk di SMP Plus Babussalam pada waktu yang telah ditentukan.

6. Setelah mengikuti ujian seleksi masuk, hasil seleksi akan diberitahukan melalui telepon atau pesan singkat.

7. Peserta PSB yang lulus harus melakukan daftar ulang pada waktu yang telah ditentukan, jika tidak maka akan dianggap mengundurkan diri.

\section{Evaluasi Prosedur yang Sedang Berjalan}

Setelah melewati tahapan analisis terhadap prosedur penerimaan siswa baru yang sedang berjalan di SMP Plus Babussalam, maka dapat diketahui kelemahan-kelemahan yang terjadi yang disajikan dalam Tabel berikut ini:

Tabel 1. Kelemahan Sistem Yang Berjalan

\begin{tabular}{|c|c|c|c|c|}
\hline No. & Objek & Faktor & Masalah & Solusi \\
\hline 1. & $\begin{array}{l}\text { Data calon } \\
\text { siswa/peserta PSB }\end{array}$ & $\begin{array}{l}\text { Data calon siswa } \\
\text { yang berisi biodata } \\
\text { masih berupa } \\
\text { fomulir kertas }\end{array}$ & $\begin{array}{l}\text { Kesulitan dalam pencarian } \\
\text { data ketika dibutuhkan dan } \\
\text { data relatif mudah nusak } \\
\text { atau hilang }\end{array}$ & $\begin{array}{l}\text { Membuat apilikasi yang dapat } \\
\text { menyimpan data ke dalam } \\
\text { suatu basis data yang } \\
\text { terintegrasi sehingga data } \\
\text { aman dan mudah untuk dicari } \\
\text { ketika dibutuhkan }\end{array}$ \\
\hline 2. & $\begin{array}{l}\text { Pengumuman dan } \\
\text { pemberitahuan } \\
\text { informasi mengenai } \\
\text { pendaftaran }\end{array}$ & $\begin{array}{l}\text { Pemberian informasi } \\
\text { masih melalui } \\
\text { telepon atau pesan } \\
\text { singkat }\end{array}$ & $\begin{array}{l}\text { Calon siswa terkadang } \\
\text { kesulitan dalam mengetahui } \\
\text { informasi lebih lanjut ketika } \\
\text { hendak maupun sudah } \\
\text { mendaftar }\end{array}$ & $\begin{array}{l}\text { Membuat aplikasi yang akan } \\
\text { memudahkan dalam } \\
\text { pemberian informasi } \\
\text { mengenai pendaftaran dan } \\
\text { bisa diakses kapan saja dan } \\
\text { dimana saja yaitu berupa } \\
\text { website }\end{array}$ \\
\hline 3. & Laporan & $\begin{array}{l}\text { Laporan yang } \\
\text { dihasilkan masih } \\
\text { direkap secara } \\
\text { manual }\end{array}$ & $\begin{array}{l}\text { Kesulitan dalam melakukan } \\
\text { rekap laporan dan } \\
\text { terlambatnya informasi yang } \\
\text { dihasilkan }\end{array}$ & $\begin{array}{l}\text { Pembuatan aplikasi yang bisa } \\
\text { mengakomodasi pembuatan } \\
\text { laporan sehingga } \\
\text { penyampaian informasi } \\
\text { menjadi efektif }\end{array}$ \\
\hline
\end{tabular}

\section{Perancangan Sistem}

Tahapan perancangan sistem adalah tahapan untuk memberikan gambaran mengenai sistem informasi penerimaan siswa baru yang akan dibuat di SMP Plus Babussalam, yang telah dianalisis ke dalam bentuk yang mudah dimengerti oleh calon pemakai (user). Adapun perancangan sistem ini mencakup pembuatan desain sistem berorientasi objek menggunakan UML (Unified Modelling Language).

\section{Use Case Diagram}

Use Case Diagram mendeskripsikan interaksi antara satu atau lebih aktor dengan sistem informasi yang akan dibuat. Berikut adalah Use Case Diagram dari perancangan sistem informasi penerimaan siswa baru berbasis web di SMP Plus Babussalam.

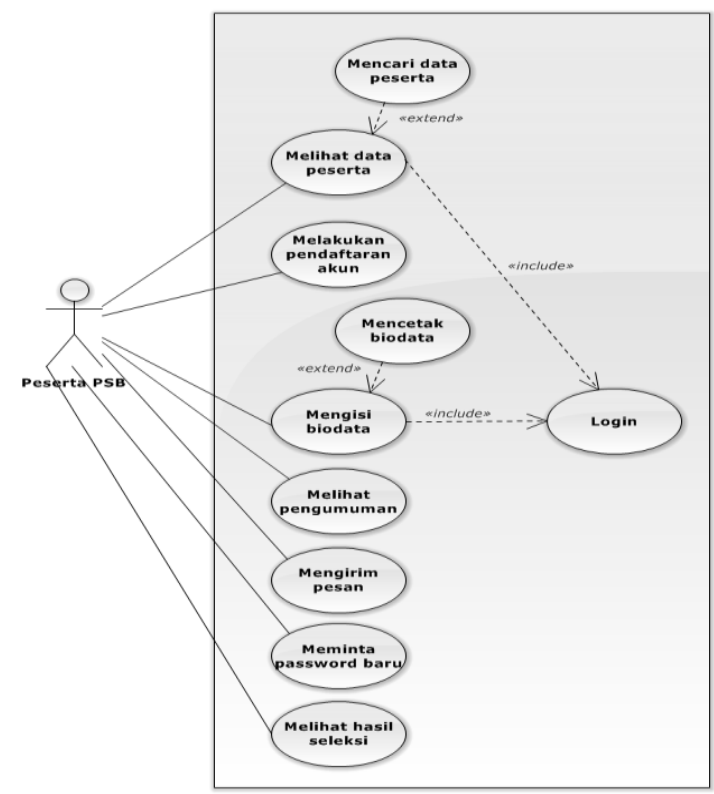

Gambar 2. Use case diagram untuk peserta PSB

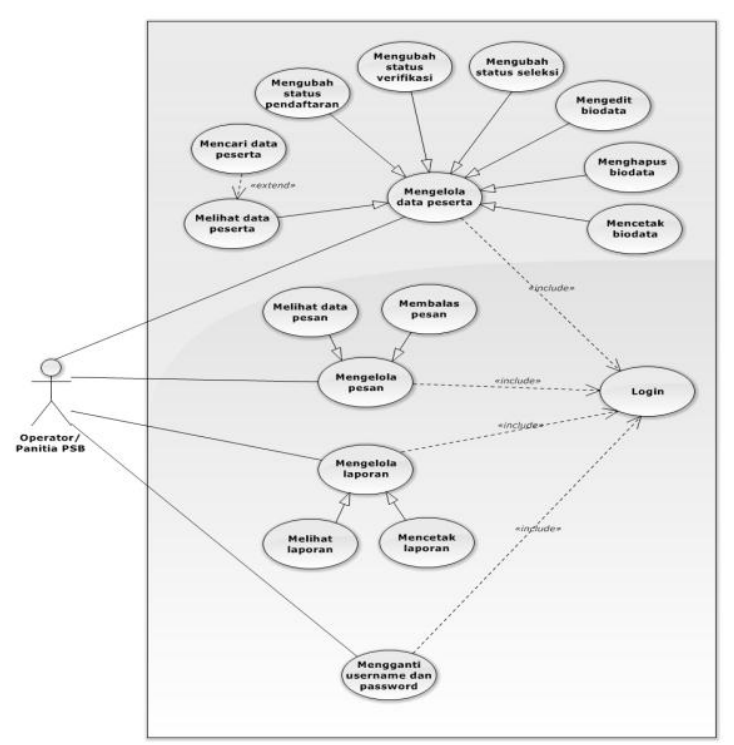

Gambar 3. Use case diagram untuk operator / panitia PSB 


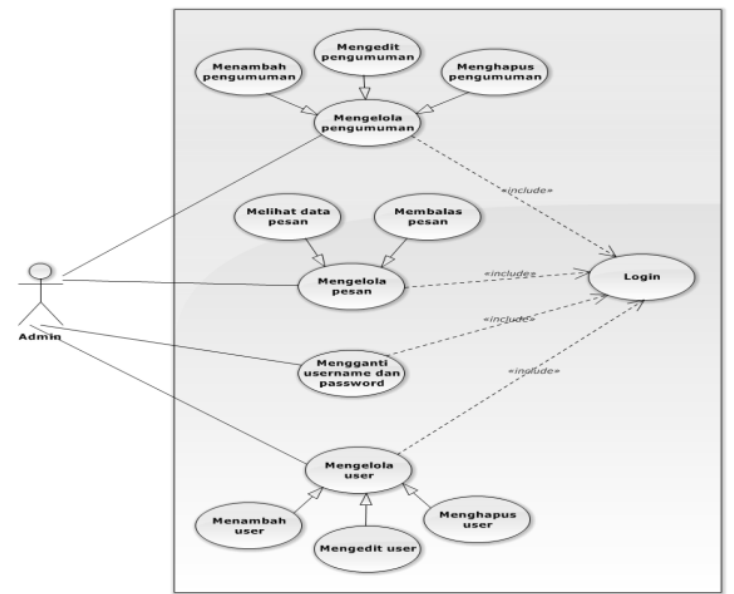

Gambar 4. Use case diagram untuk admin

\section{Activity Diagram}

Activity diagram menggambarkan workflow (aliran kerja) atau aktivitas dari sebuah sistem dan user. Berikut ini adalah activity diagram dalam perancangan sistem informasi penerimaan siswa baru berbasis web di SMP Plus Babussalam

\section{Activity Diagram Peserta PSB}

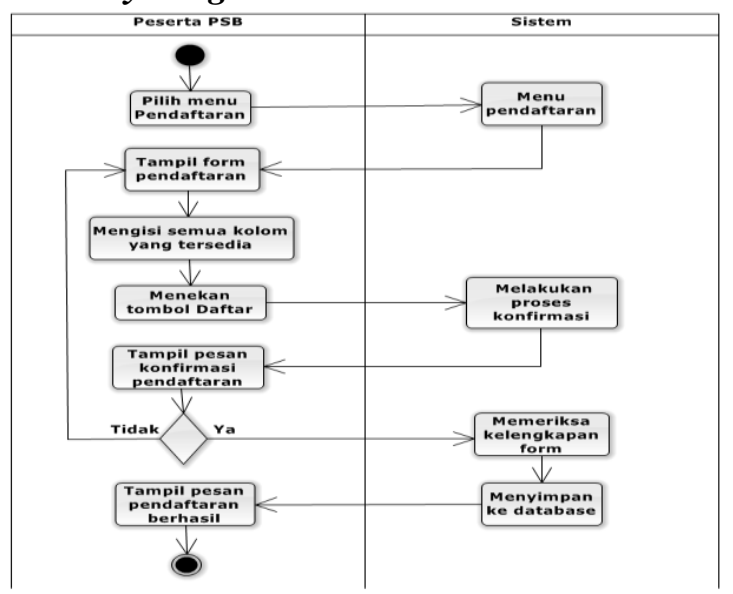

Gambar 5. Activity diagram melakukan pendaftaran akun

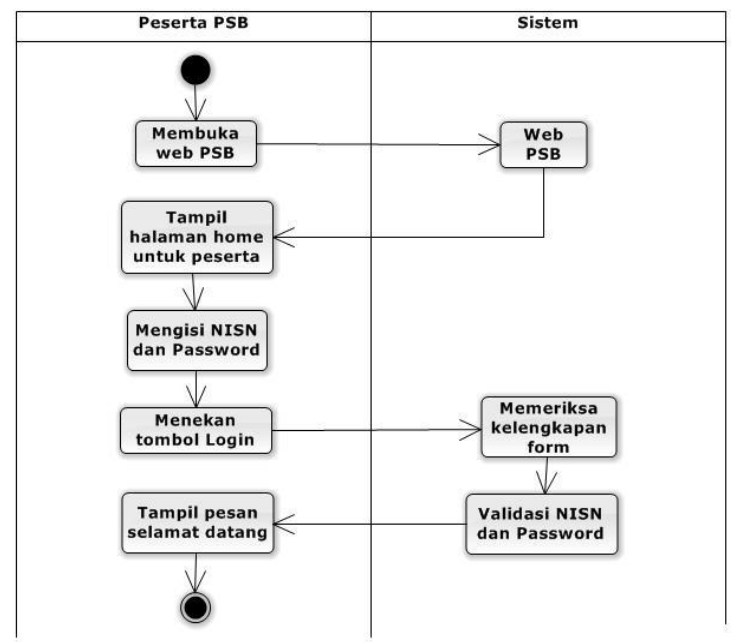

Gambar 6. Activity diagram login untuk peserta PSB

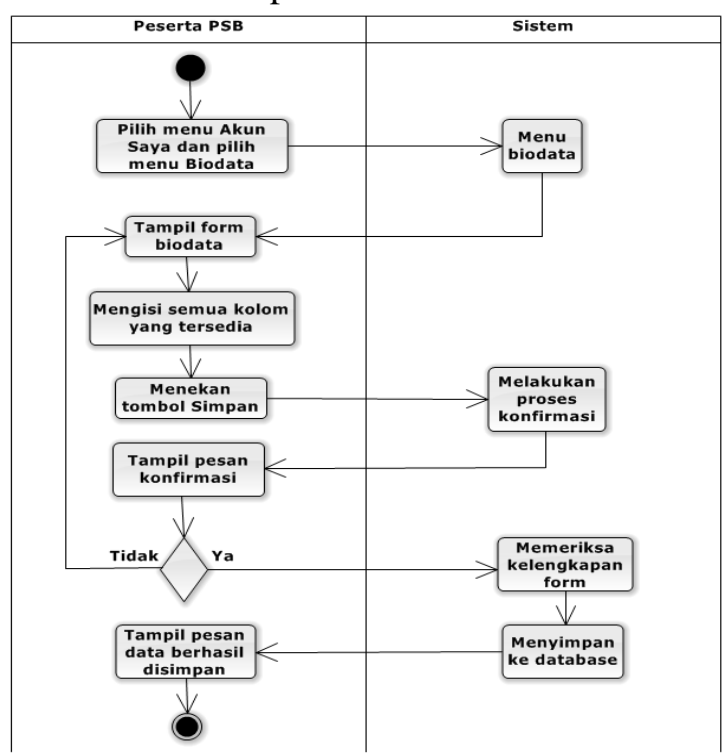

Gambar 7. Activity diagram mengisi biodata

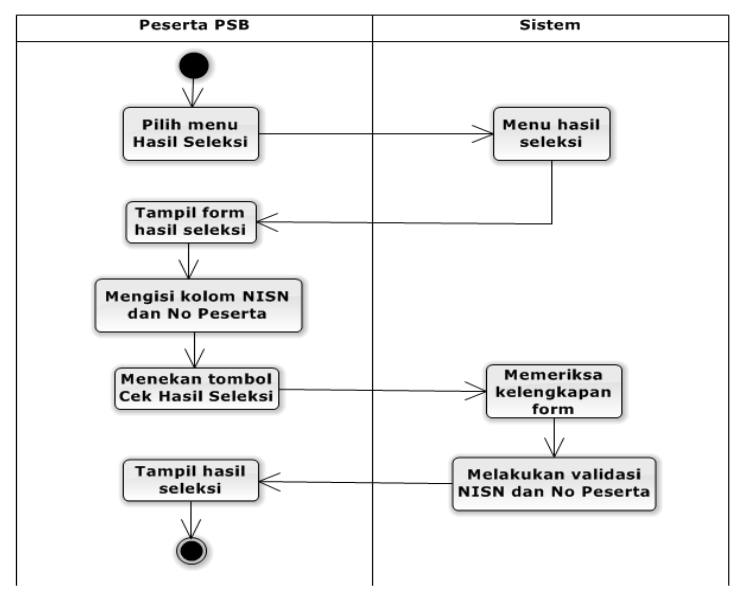

Gambar 8. Activity diagram melihat hasil seleksi 


\section{Activity Diagram Operator/Panitia PSB}

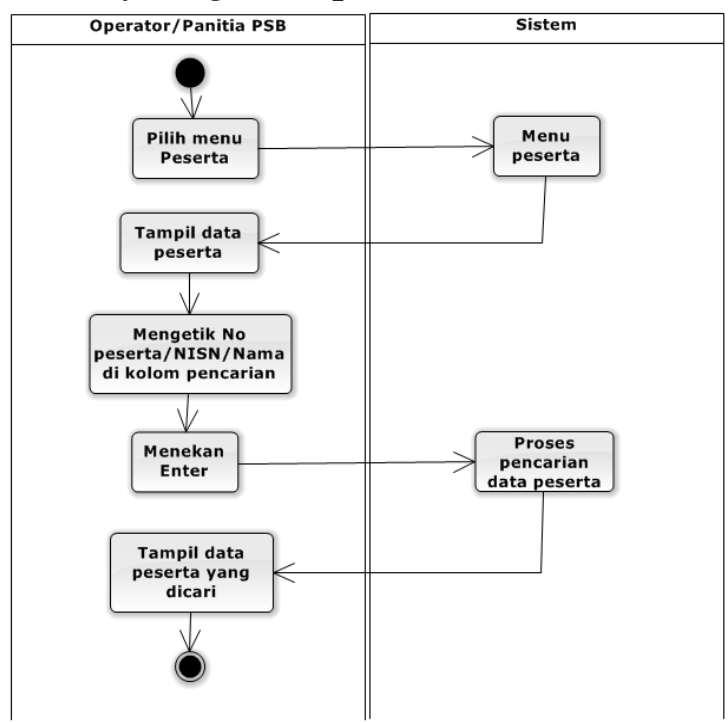

Gambar 9. Activity diagram mencari data peserta untuk operator

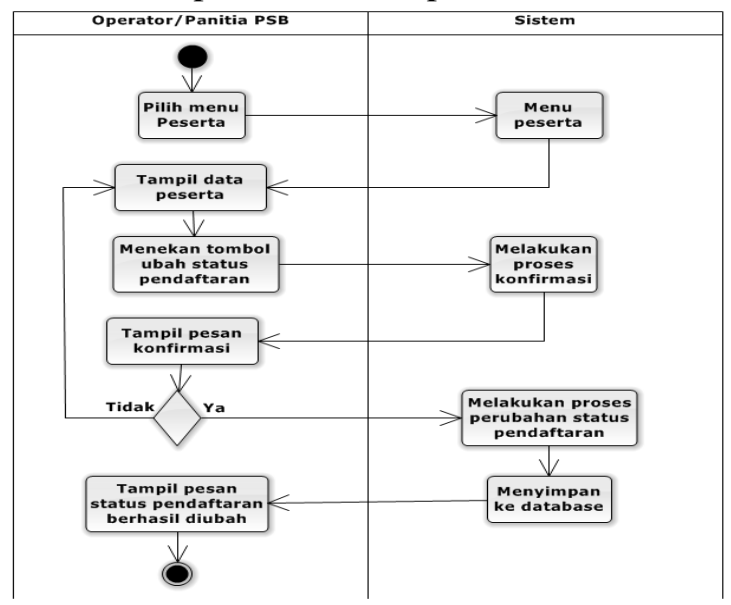

Gambar 10. Activity diagram mengubah status pendaftaran

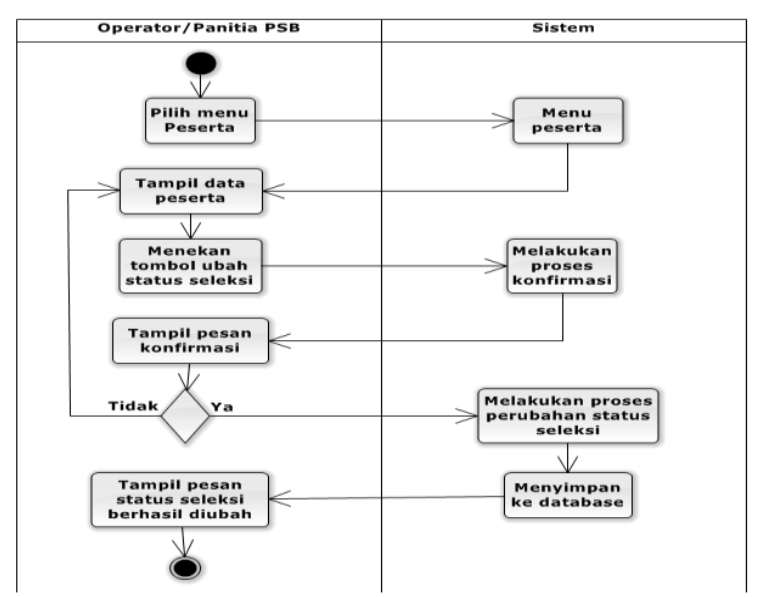

Gambar 11. Activity diagram mengubah status seleksi
Activity Diagram Admin

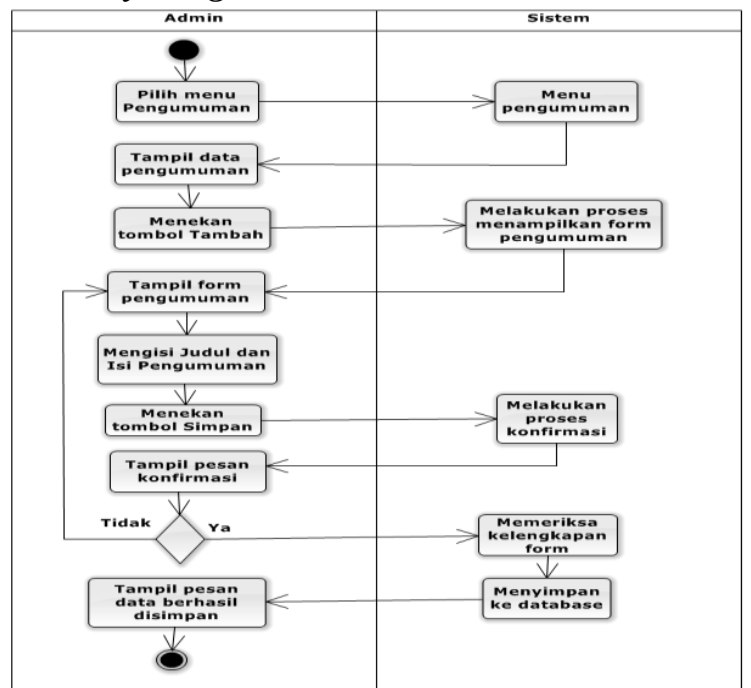

Gambar 12. Activity diagram menambah pengumuman

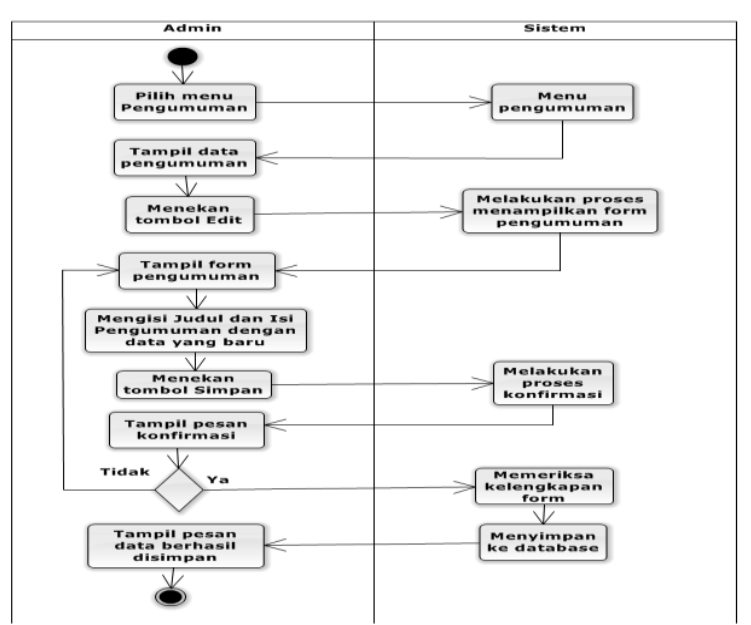

Gambar 13. Activity diagram mengedit pengumuman

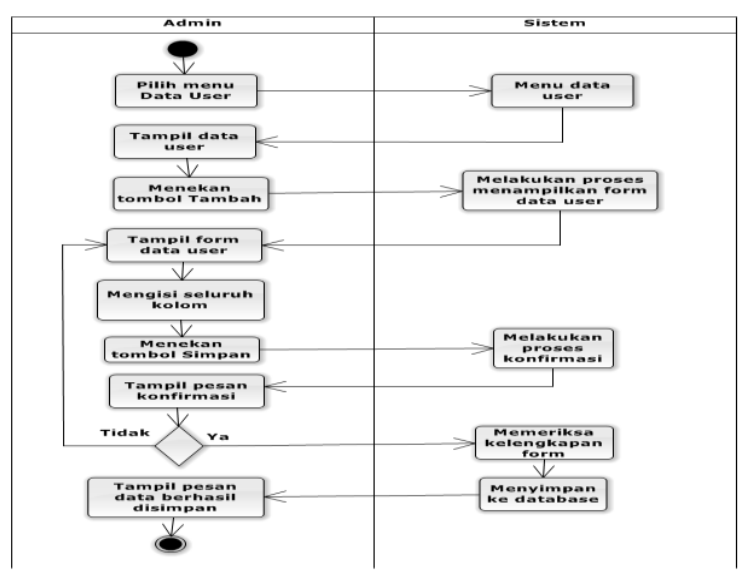

Gambar 14. Activity diagram menambah user Class Diagram 
Class Diagram menggambarkan sistem dari segi pendefinisian kelas-kelas yang akan dibuat untuk membangun sistem.
Berikut adalah class diagram dalam perancangan sistem informasi penerimaan siswa baru berbasis web di SMP Plus Babussalam.

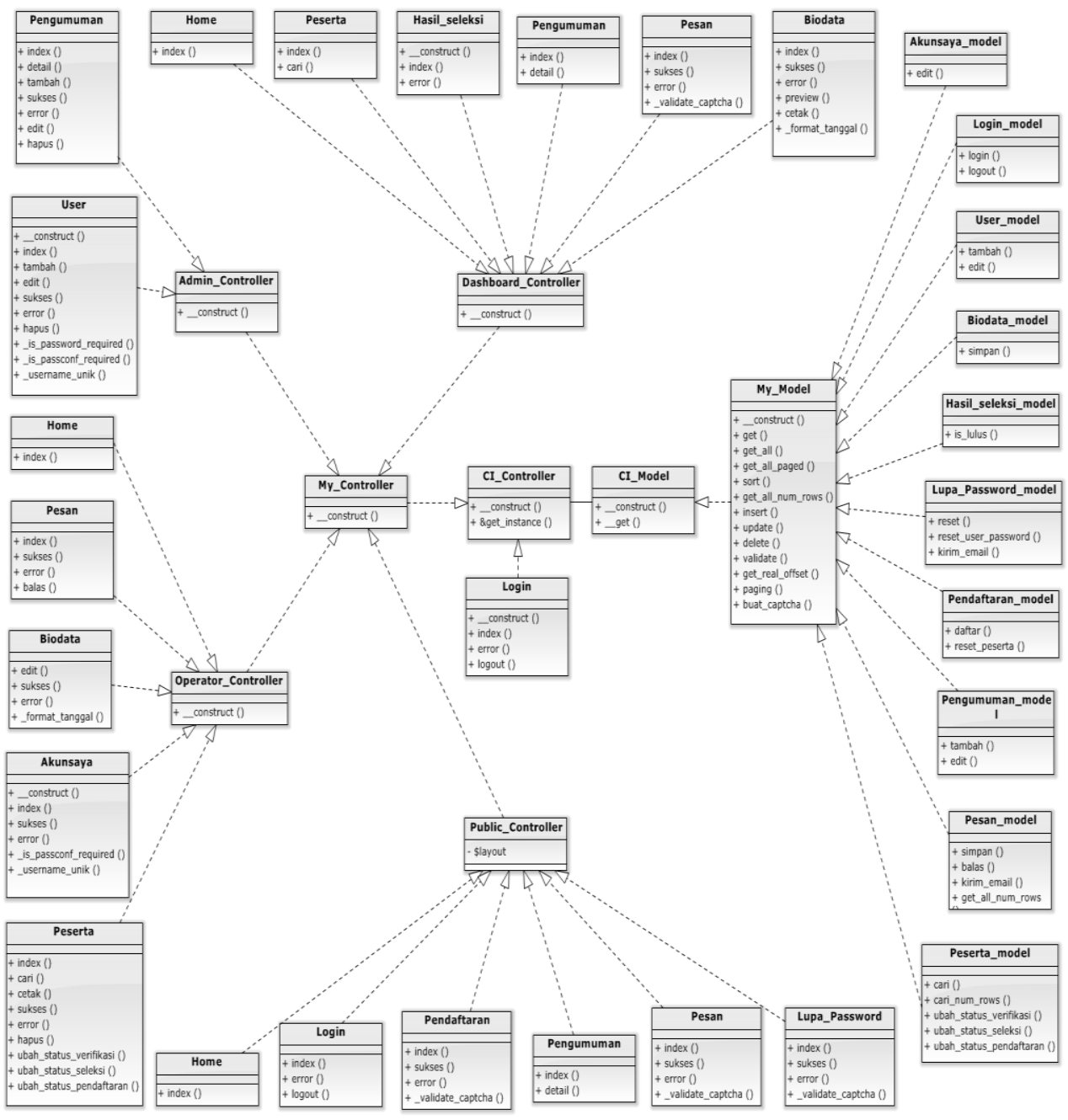

Gambar 15. Class diagram sistem informasi penerimaan siswa baru berbasis web.

Perancangan basis data adalah proses untuk menentukan isi dan pengaturan data yang dibutuhkan untuk mendukung perancangan sistem. Berikut adalah

\section{Perancangan Basis Data}

perancangan basis data dari sistem informasi penerimaan siswa baru berbasis web di SMP Plus Babussalam. 


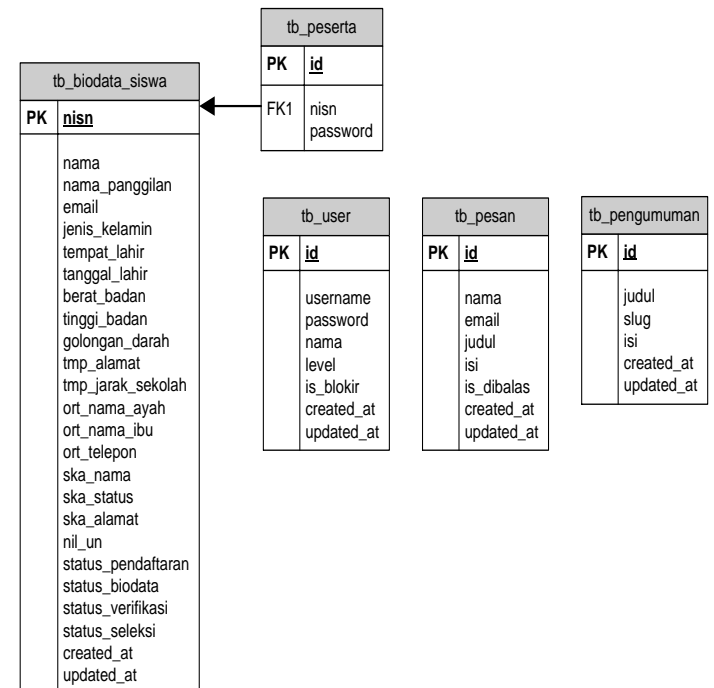

Gambar 16. Tabel fisik perancangan basis data penerimaan siswa baru berbasis web

\section{Perancangan Antar Muka}

Perancangan antar muka adalah perancangan tampilan setiap halaman dari sebuah sistem informasi. Perancangan antar muka dalam penelitian ini dibagi menjadi 3 bagian yakni tampilan antar muka yang dapat diakses oleh Peserta PSB, Operator, dan Admin.

\section{Perancangan Antar Muka untuk Peserta PSB}

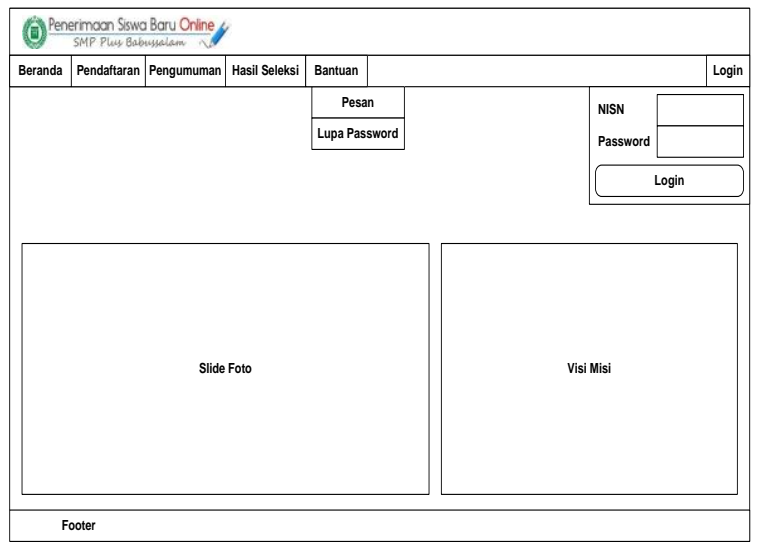

Gambar 17. Desain tampilan beranda untuk peserta PSB sebelum login

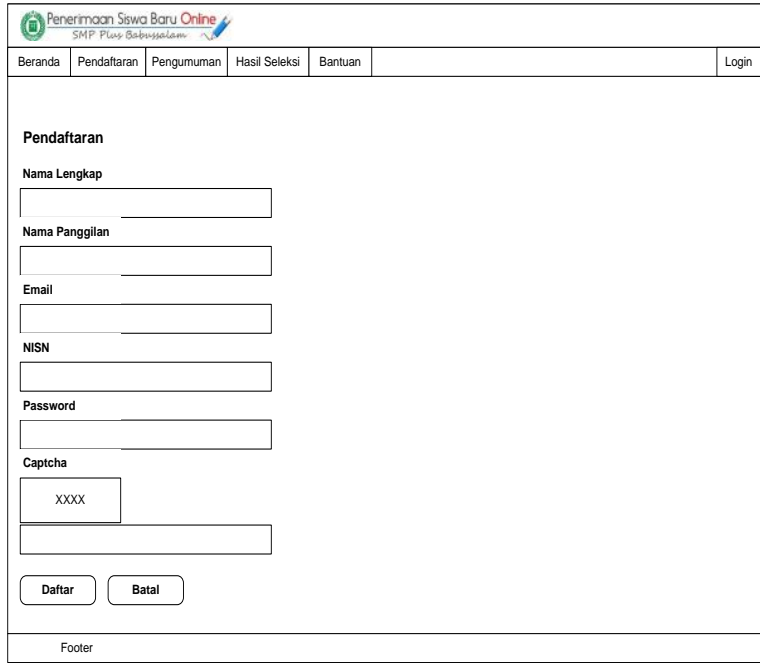

Gambar 18. Desain tampilan halaman pendaftaran

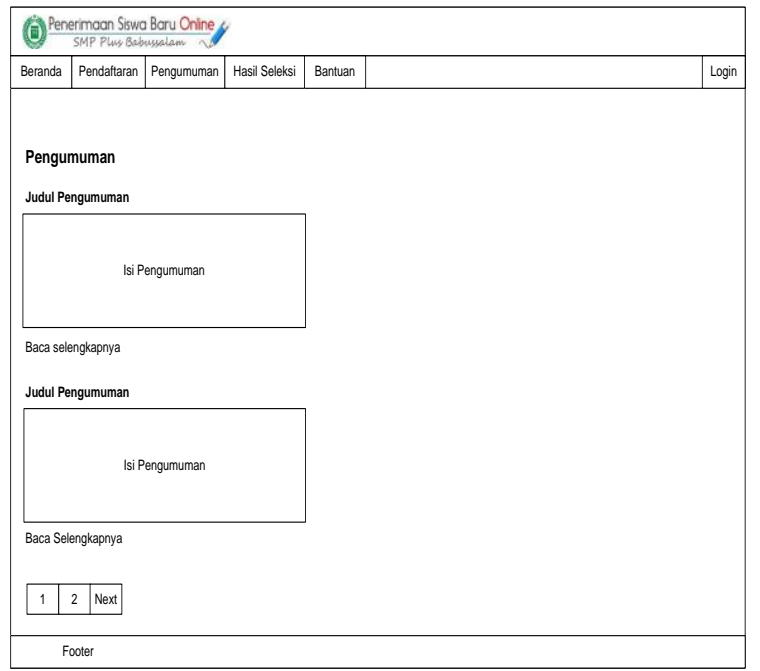

Gambar 19. Desain tampilan halaman pengumuman 


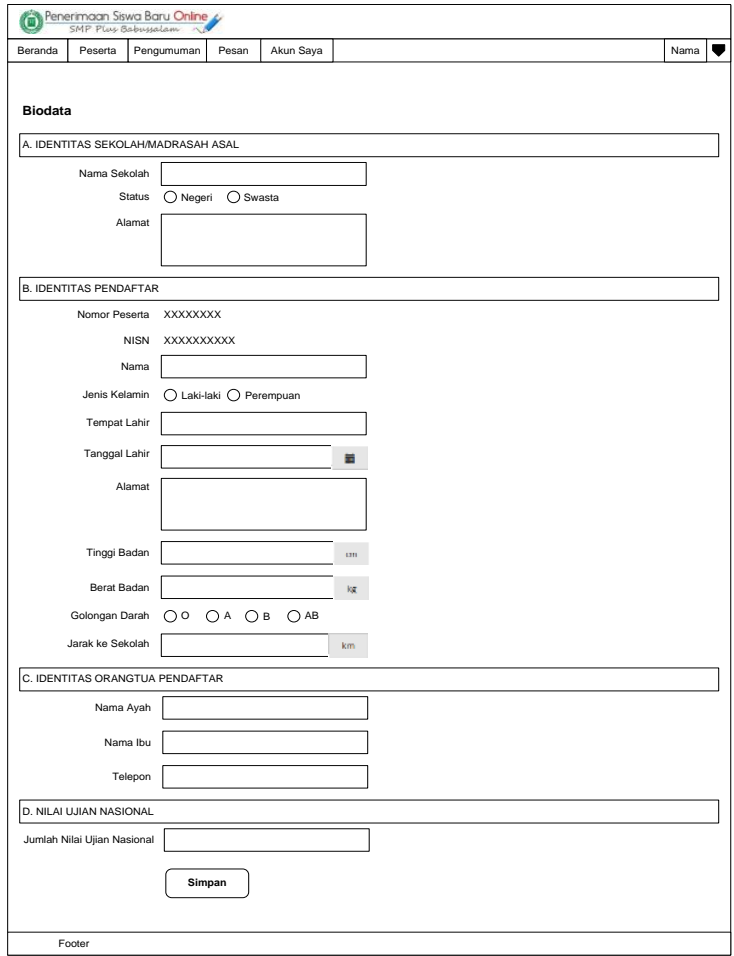

Gambar 20. Desain tampilan halaman biodata untuk peserta PSB

Perancangan Antar Muka untuk Operator

\begin{tabular}{|c|c|c|c|c|c|c|c|}
\hline Beranc & $\begin{array}{lll}\text { ta } & \text { Data Pese }\end{array}$ & $\begin{array}{ll}\text { Pesan } \\
\end{array}$ & Akun Saya & & & & \begin{tabular}{|l|l|} 
usemane & $\mathbf{V}$ \\
\end{tabular} \\
\hline \multicolumn{8}{|c|}{ Data Peserta PSB Tahun Ajaran XXXXXXXXX } \\
\hline \multicolumn{8}{|c|}{ Masulkan No Peserta, NSSN, Nama } \\
\hline No & No Peserta & NSW & Nama & Status Pendatataran & Status Biodata & Status Verifikasi & Status Seltesi $\mid$ Aksi \\
\hline 1. & & & & & & & 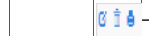 \\
\hline 2. & & & & & & & 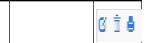 \\
\hline 3. & & & & & & & $8 \pm 1$ \\
\hline 1 & \begin{tabular}{|l|l|}
2 & Next \\
\end{tabular} & & & & & & Cetak Laovoran \\
\hline
\end{tabular}

Gambar 21. Desain tampilan halaman data peserta untuk operator

Perancangan Antar Muka untuk Admin

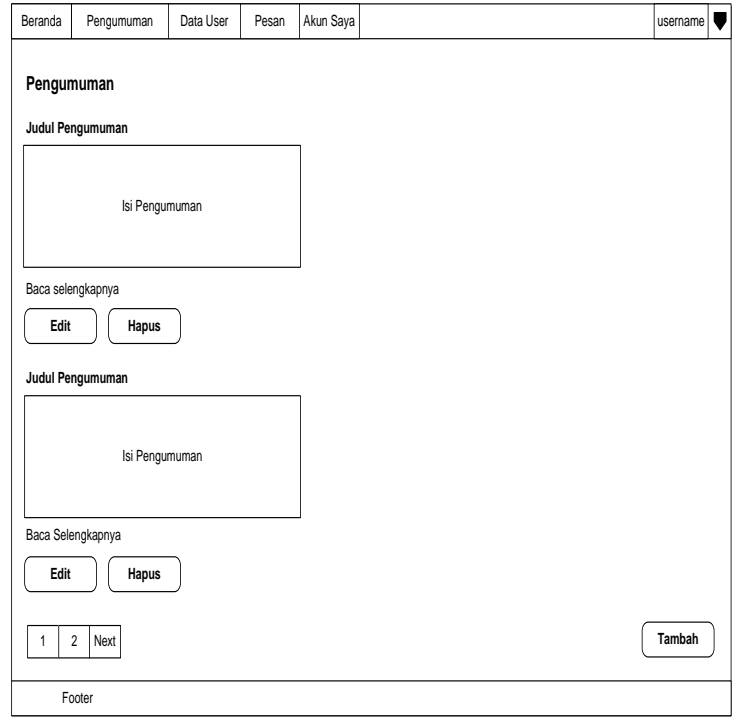

Gambar 22. Desain tampilan halaman pengumuman untuk admin

\section{Perancangan Output}

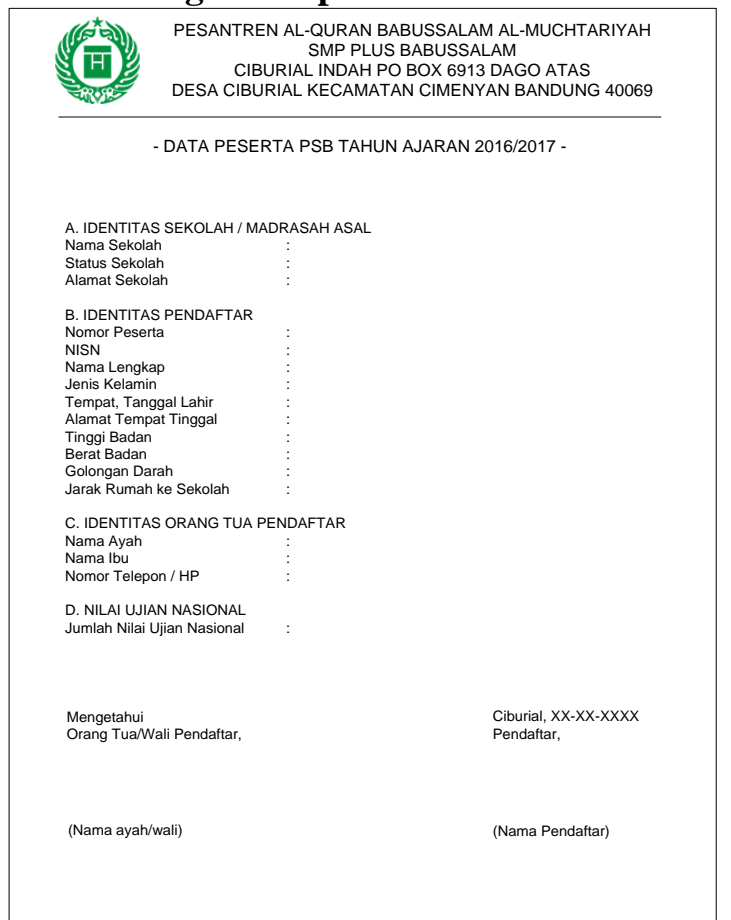

Gambar 23. Desain tampilan Biodata Peserta PSB untuk dicetak.

\section{Perancangan Arsitektur Jaringan}

Dalam perancangan arsitektur jaringan, digunakan metode konfigurasi jaringan internet. Karena sistem informasi penerimaan siswa baru yang akan dibangun ini merupakan aplikasi website yang akan menggunakan akses internet didalam penggunaannya.

Berikut adalah perancangan arsitektur jaringan dari sistem informasi penerimaan siswa baru berbasis web di SMP Plus Babussalam. 


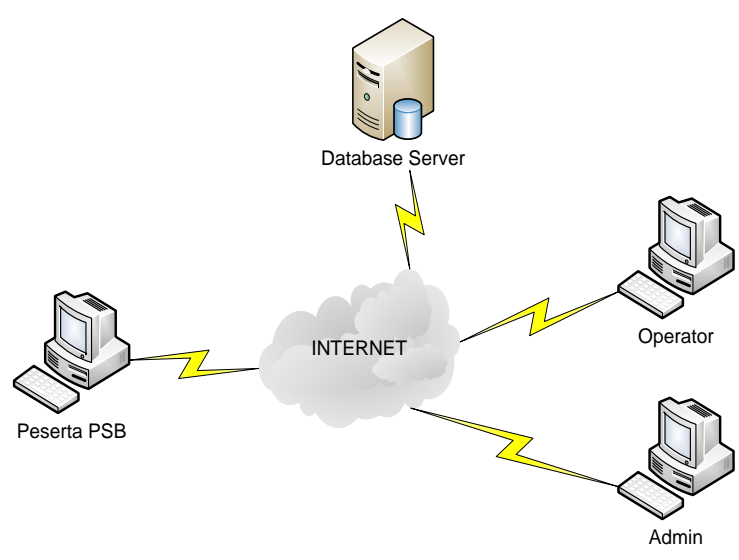

Gambar 24. Desain Arsitektur Jaringan Sistem Informasi penerimaan siswa baru berbasis web di SMP Plus Babussalam.

\section{Implementasi Program}

Adapun implementasi dari perancangan antarmuka aplikasi yang telah dirancang dapat dilihat sebagai berikut :

$$
\text { 0. Penerimoan Siswa Baru Online, }
$$

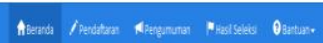

loge.

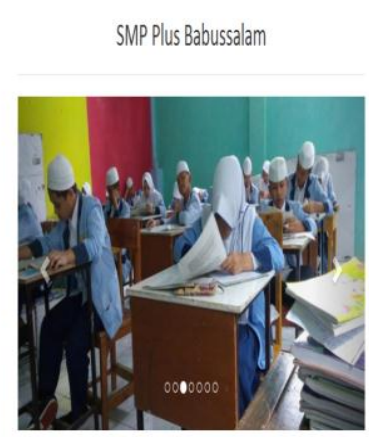

Visi Misi

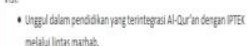

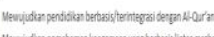

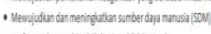

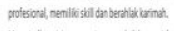

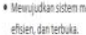

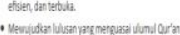

Gambar 25. Tampilan halaman beranda peserta PSB sebelum login
(1) Penerimaan Siswa Baru Onine

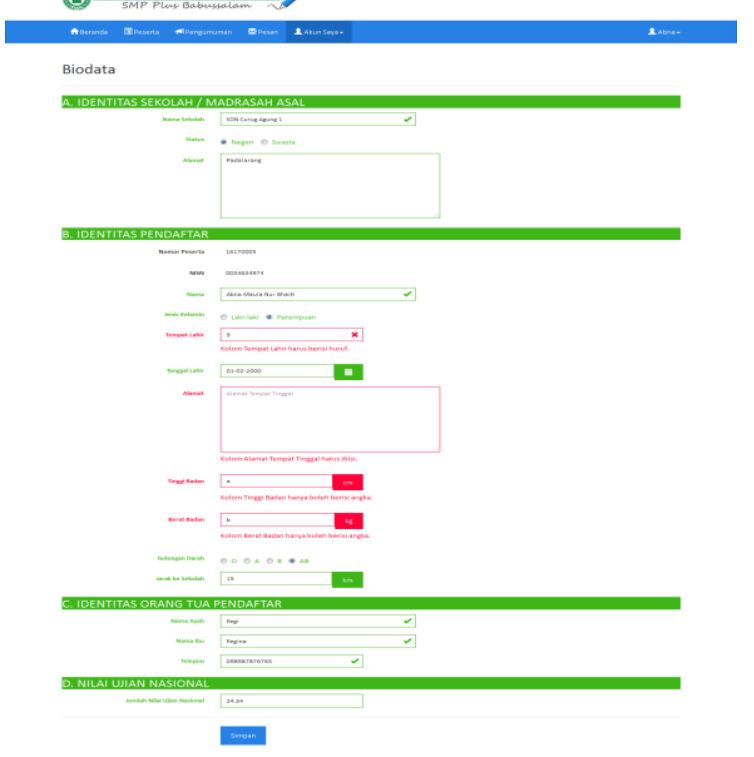

Gambar 26. Tampilan form biodata

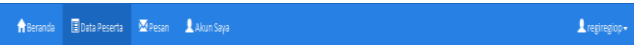

Data Peserta PSB Tahun Ajaran 2016/2017
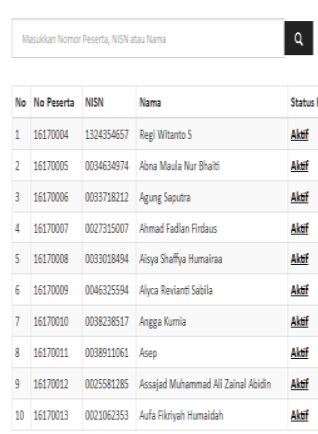

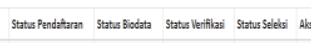

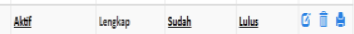

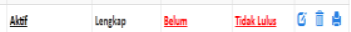

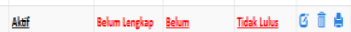

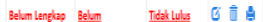

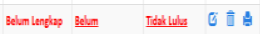

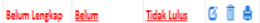

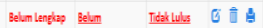

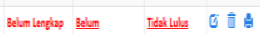

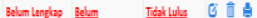

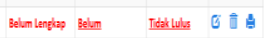

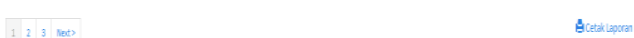

Gambar 27. Tampilan halaman data peserta 


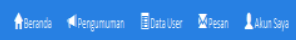

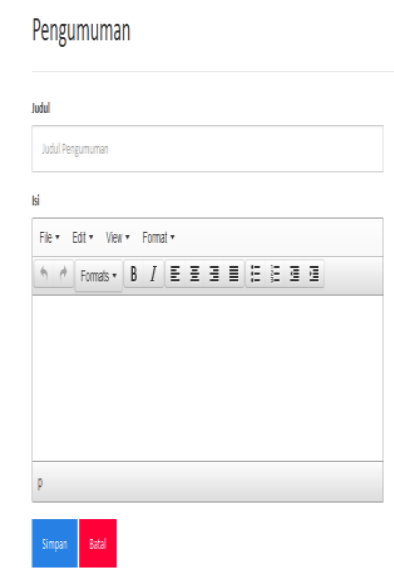

Gambar 28. Tampilan form tambah pengumuman

\section{KESIMPULAN}

Berdasarkan analisis, perancangan yang telah dilakukan dalam pembuatan sistem informasi penerimaan siswa baru berbasis web di SMP Plus Babussalam ini maka dapat diambil beberapa kesimpulan sebagai berikut:

1. Sistem informasi penerimaan siswa baru berbasis web dari hasil penelitian ini dapat memberi kemudahan akses informasi dan proses pendaftaran bagi calon siswa.

2. Sistem informasi penerimaan siswa baru berbasis web ini juga dapat mengatasi pengolahan data calon siswa menjadi lebih baik karena disimpan dalam suatu basis data yang terintegrasi.

3. Proses administrasi penerimaan siswa baru menjadi lebih efektif dan efisisen sehingga memberi kemudahan bagi para panitia penerimaan siswa baru di SMP Plus Babussalam.

\section{REFERENSI}

[1] Al-Bahra. 2005. Analisis dan Desain Sistem Informasi. Graha Ilmu. Yogyakarta.

[2] Irawan, Budhi. 2005. Jaringan Komputer. Graha Ilmu. Yogyakarta.

[3] Jogiyanto, HM. 2005. Analisis Dan Desain Sistem Informasi : Pendekatan Terstruktur, Teori Dan Praktik Aplikasi Bisnis. Andi. Yogyakarta.

[4] Kristanto, Andi. 2008. Perancangan Sistem Informasi dan Aplikasinya. Gava Media. Yogyakarta.

[5] Sherlyta, Olivia. 2013. Pembangunan Sistem Penerimaan Siswa Baru Secara Online Pada TK \& SD Model Sleman. STMIK AMIKOM. Yogyakarta Didapat dari repository.amikom.ac.id/files/Publikasi_0 9.11.2866.pdf

[6] Pressman, Roger S. 2002. Rekayasa Perangkat Lunak. Andi. Yogyakarta.

[7] Shalahudin, M., dan Rosa A.S. 2013. Rekayasa Perangkat Lunak Terstruktur dan Berorientasi Objek. Informatika. Bandung.

[8] Simarmata, Janner. 2007. Perancangan Basis Data. Andi. Yogyakarta.

[9] Widodo, Prabowo P \& Herlawati. 2011. Menggunakan UML - UML Secara Luas Digunakan untuk Memodelkan Analisis \& Desain Sistem Berorientasi Objek. Informatika. Bandung. 